\title{
Resolving the abundance and air-sea fluxes of airborne microorganisms in the North Atlantic Ocean
}

\author{
Eva Mayol ${ }^{1 *}$, María A. Jiménez' ${ }^{1}$, Gerhard J. Herndl ${ }^{2}$, Carlos M. Duarte ${ }^{1,3}$ and Jesús M. Arrieta ${ }^{1}$ \\ Department of Global Change Research, Institut Mediterrani d'Estudis Avançats, Consejo Superior de Investigaciones Cientificas - Universitat de les Illes Balears, \\ Mallorca, Spain \\ ${ }^{2}$ Department of Limnology and Bio-Oceanography, Center of Ecology, University of Vienna, Vienna, Austria \\ ${ }^{3}$ The UWA Oceans Institute, The University of Western Australia, Crawley, WA, Australia
}

\section{Edited by:}

Hongyue Dang, Xiamen University,

China

Reviewed by:

Susannah Marie Burrows, Pacific Northwest National Laboratory, USA

Cindy E. Morris, National Institute of Agronomic Research, France

*Correspondence:

Eva Mayol, Department of Global Change Research, Institut

Mediterrani d'Estudis Avançats,

Consejo Superior de Investigaciones Cientificas - Universitat de les Illes

Balears, Miquel Marqués 21.

Mallorca 07190, Spain

e-mail:emayol@imedea.uib-csic.es
Airborne transport of microbes may play a central role in microbial dispersal, the maintenance of diversity in aquatic systems and in meteorological processes such as cloud formation. Yet, there is almost no information about the abundance and fate of microbes over the oceans, which cover $>70 \%$ of the Earth's surface and are the likely source and final destination of a large fraction of airborne microbes. We measured the abundance of microbes in the lower atmosphere over a transect covering $17^{\circ}$ of latitude in the North Atlantic Ocean and derived estimates of air-sea exchange of microorganisms from meteorological data. The estimated load of microorganisms in the atmospheric boundary layer ranged between $6 \times 10^{4}$ and $1.6 \times 10^{7}$ microbes per $\mathrm{m}^{2}$ of ocean, indicating a very dynamic air-sea exchange with millions of microbes leaving and entering the ocean per $\mathrm{m}^{2}$ every day. Our results show that about $10 \%$ of the microbes detected in the boundary layer were still airborne 4 days later and that they could travel up to $11,000 \mathrm{~km}$ before they entered the ocean again. The size of the microbial pool hovering over the North Atlantic indicates that it could play a central role in the maintenance of microbial diversity in the surface ocean and contribute significantly to atmospheric processes.

Keywords: airborne microorganisms, microbial dispersal, air-sea exchange, bioaerosols, Atlantic Ocean

\section{INTRODUCTION}

Airborne microbes are ubiquitous in the atmosphere (Després et al., 2012) and are thought to play important roles in meteorological processes such as the formation of clouds and snow (Christner et al., 2008; Morris et al., 2014), the long-range dispersal of pathogens (Polymenakou et al., 2007) and the maintenance of the diversity in aquatic systems (Hervàs et al., 2009). Global emissions of bacteria have been estimated, based on data from terrestrial environments, to range between 40 and $1800 \mathrm{Gg}$ $\mathrm{a}^{-1}$ dry weight (Burrows et al., 2009a). This estimate is poorly constrained due to the paucity of estimates of the abundance of airborne microbes (Burrows et al., 2009a), particularly for oceanic locations, where the few estimates available correspond to coastal locations (Burrows et al., 2009b). The airborne microbial community over the open ocean, comprising the largest share of Earth's surface, has thus far been neglected. Moreover, a large fraction of the available data refer to cultivable bacteria (Burrows et al., 2009b), which yield very low estimates $(<1 \%)$ of total microbial abundance and diversity (Amann et al., 1995). More recent studies have incorporated direct counting by microscopy or quantitative PCR (Cho and Hwang, 2011; Smith et al., 2012; DeLeon-Rodriguez et al., 2013), yielding more accurate, higher estimates of the abundance of airborne microbes. Flux measurements are even more scarce and mostly limited to land and coastal locations since direct measurements are virtually impossible on the open sea (Petelski and Piskozub, 2006).
Hence, our knowledge on airborne microbes over the oceans is very limited compared to that on microbes inhabiting aquatic and terrestrial environments. Addressing this gap requires that estimates of the abundance of airborne microbes need to be extended to include the atmospheric boundary layer over the ocean, and that the dynamics of the airborne bacteria, in terms of the atmospheric transport of microbes and the exchange of microbes between the atmosphere and the ocean, be quantified to assess the impact of airborne microbes on climate and atmospheric processes (Morris et al., 2014).

In this study we establish an approach for the quantitative assessment of the abundance of microorganisms in the atmosphere over the open ocean using commercially available equipment. Air-sea exchange of microbes and the potential for dispersal were then estimated using available measurements and different parameterizations resulting in the first quantitative estimates of abundance and air-sea exchange of microorganisms for the North Atlantic Ocean.

\section{MATERIALS AND METHODS SAMPLING AND MICROBIAL ABUNDANCE}

Samples of airborne microbes were collected at different locations in the North Atlantic Ocean during the MEDEA-II cruise on board R/V Pelagia, from mid-June to mid-July 2012. Thirty-one aerosol samples were collected along the cruise track covering a range of approximately 17 latitudinal degrees from $49.8^{\circ}$ to $67^{\circ} \mathrm{N}$ (Figure 1). 


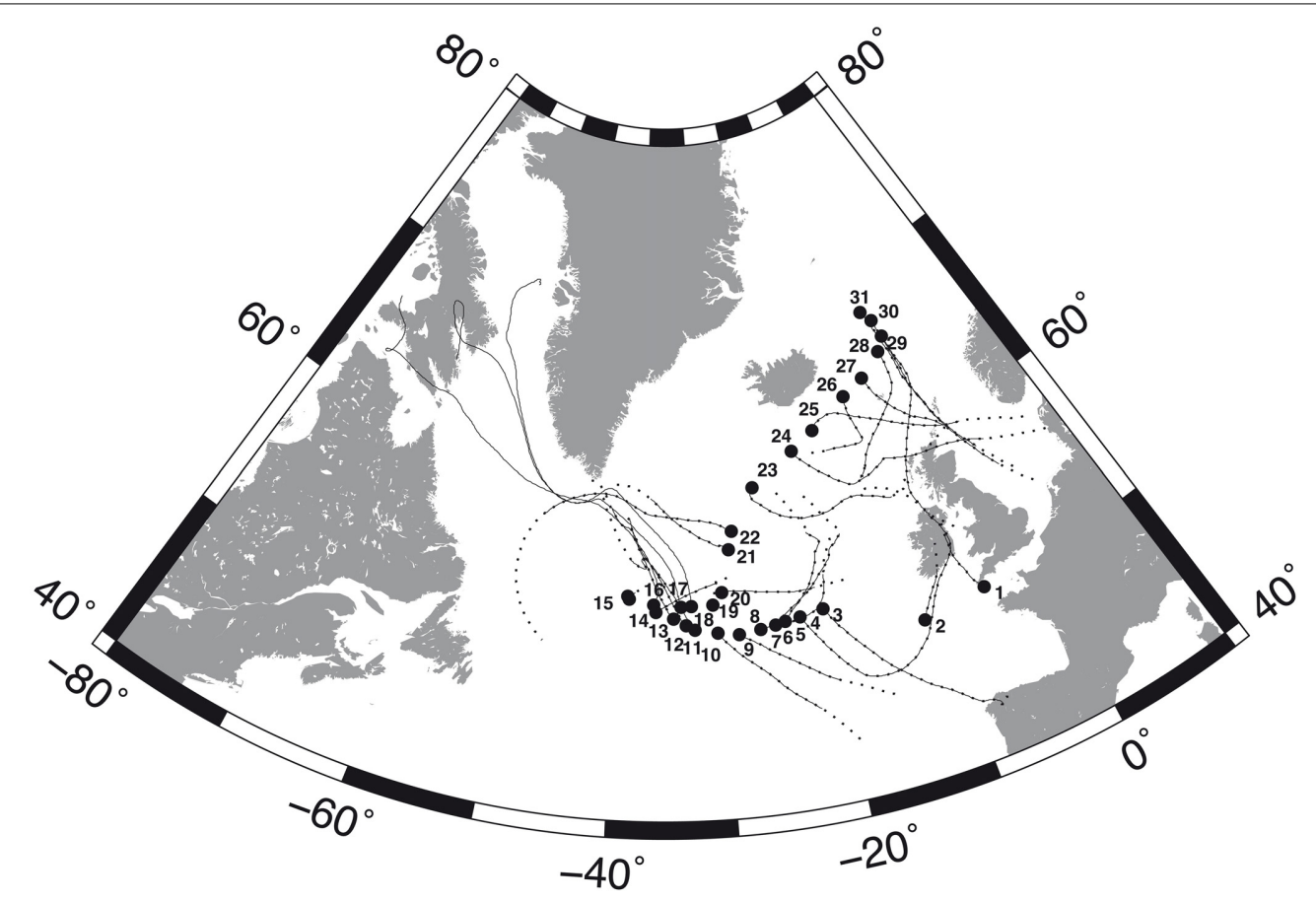

FIGURE 1 | Sampling sites (black circles) along the MEDEA-Il cruise and forward trajectories of the air masses during the calculated time for remaining prokaryotic (continuous lines) and eukaryotic (broken lines) loads of $10 \%$.

Air sampling was carried out using a commercially available cyclonic collector (Coriolis- $\Delta$, Bertin Technologies; Carvalho et al., 2008) placed at bow-side at $\sim 10 \mathrm{~m}$ height over sea level at the top deck of R/V Pelagia. The inlet piece and all the pieces in contact with the sample and the collection liquid were cleaned before every sampling by immersion in diluted $\mathrm{HCl}(0.5 \mathrm{~N})$ for $12 \mathrm{~h}$, rinsed with freshly produced $0.2 \mu \mathrm{m}$ filter-sterilized MilliQ water to remove microbial contamination and carried to the sampler covered in clean Ziploc bags. Samples were collected only when the ship was steaming forward and into the wind according to underway measurements of relative wind direction and speed to avoid shipborne contamination. The collection liquid was prepared fresh every day by sterile filtration $(0.2 \mu \mathrm{m})$ and consisted of Milli-Q water containing $0.005 \%$ Triton X-100. Air was drawn into the sampler at $300 \mathrm{l}$ per minute for $6 \mathrm{~h}$ (equivalent to $108 \mathrm{~m}^{3}$ ), and the collection liquid was refilled continuously by the system at a rate sufficient to match the loss of liquid by evaporation and re-aerosolization measured during a previous $10 \mathrm{~min}$ run. Daily, a field blank was collected by sampling air for $2 \mathrm{~min}$ (equivalent to $0.6 \mathrm{~m}^{3}$ ).

Samples were processed immediately after collection and the volume adjusted to $15 \mathrm{ml}$ with additional collection liquid if necessary. Five milliliter aliquots of sample were fixed with formaldehyde ( $2 \%$ final concentration) for $10 \mathrm{~min}$, stained with DAPI (4', 6- diamidino-2-phenylindole, $1 \mu \mathrm{g} \mathrm{ml}^{-1}$ final concentration) and subsequently filtered onto black $0.2 \mu \mathrm{m}$ pore size polycarbonate filters (Millipore), mounted on microscope slides and stored frozen for later analysis of the abundance of prokaryotes and unicellular eukaryotes. DAPI-stained samples were examined using a Leika DM 1000 epifluorescence microscope equipped with an HBO 50 mercury arc lamp and a filter cube containing a 360/40 BP excitation filter, a $400 \mathrm{~nm}$ dichromatic mirror and a $470 / 40 \mathrm{BP}$ emission filter. DAPI bound to DNA results in bright blue fluorescence at $\sim 390 \mathrm{~nm}$ when excited with $365 \mathrm{~nm}$ light while DAPI bound to other materials appears as weak yellow or non-fluorescent (Porter and Feig, 1980). Thus, biological (DNA-containing) particles can be readily discriminated from inorganic particles and organic debris using this setup. DNA containing particles approximately smaller than $1 \mu \mathrm{m}$ and uniformly stained (no clearly defined nucleus) were counted as prokaryotes while larger cells presenting clearly defined, brightly stained nuclei were counted as unicellular eukaryotes (Sherr et al., 1993) to a point.

No traces of multicellular eukaryotic tissue were found in any of the samples. Because of the highly variable abundance of airborne organisms in our samples, we established a counting strategy aimed at providing high precision counts at very low abundances assuming a Poisson distribution. At least 150 particles of interest (bacteria or unicellular eukaryotes) were counted per sample in at least 12 different fields. In samples with very low abundances like field blanks where 150 particles could not be detected, at least 150 fields were counted. This strategy allowed us to ensure a good overall precision $(<10 \%$ relative standard deviation) even in those samples with very low abundances. Additionally, we determined bacterial abundance in surface seawater by flow cytometry of SYBRGreen I stained samples (Marie et al., 1997). Seawater was collected from the mixed layer with Niskin bottles mounted on a rosette sampling system. 


\section{ACCOUNTING FOR LOSS OF PARTICLES BY RE-AEROSOLIZATION}

One of the caveats of liquid-based samplers is that some of the sample will be inevitably re-aerosolized and carried away by the air flowing through the system (Willeke et al., 1998; Riemenschneider et al., 2010). Thus, we quantified the loss of $1 \mu \mathrm{m}$-size particles over time in our collector using the conditions of air flow as in the field sampling. We did so by adding $1 \mu \mathrm{m}$ diameter fluorescently labeled polystyrene microspheres (Invitrogen) to the collection cups at the onset of the run $\left(\sim 250,000\right.$ beads $\left.\mathrm{ml}^{-1}\right)$ and evaluating the abundance of the beads remaining at $1 \mathrm{~h}$ intervals using flow cytometry. Since the volume in the collection cup is kept constant, we can assume that the collection liquid is aerosolized at a constant rate and becoming more diluted over time. Thus, we can model the number of particles $\mathrm{N}$ (particles $\mathrm{ml}^{-1}$ ) in the liquid over time as

$$
\frac{d N}{d t}=k \cdot N
$$

which for an initial abundance $N_{0}=N(t=0)$ can be solved as the exponential function

$$
N(t)=N_{0} \cdot e^{k \cdot t}
$$

Fitting the measured abundances of fluorescent particles in the sampler over time by nonlinear regression to Equation (2), we obtained an excellent fit $\left(R^{2}=0.993\right)$ and an estimate of $k=(-0.770 \pm 0.049) \mathrm{h}^{-1}$ (mean values \pm standard error).

Thus, assuming that microbial abundance in the air is constant over the sampling period, microbial particles (prokaryotic or eukaryotic) enter the sampler at a constant rate $c$. Then the accumulation of particles in the sampling cup can be expressed as

$$
\frac{d N}{d t}=-0.7701 N+c
$$

which for an initial number of particles in the sampling cup $N$ (field blank) gives

$N(t)=1.29853 c+0.999998 N_{0} \cdot e^{-0.7701 t}-1.29853 c \cdot e^{-0.7701 t}$

where $N(t)$ is the observed microbial abundance (particles $\mathrm{ml}^{-1}$ ) in the collected sample and $N_{0}$ the observed abundance in the field blank. From this equation we obtained the rate of entry of microbial particles in the sampling cup (c, particles $\left.\mathrm{ml}^{-1} \mathrm{~h}^{-1}\right)$ as

$$
c=\frac{0.999998 N_{0} \cdot e^{-0.7701 t}-N(t)}{1.29853 e^{-0.7701 t}-1.29853}
$$

Our standard sampling conditions (300 l of air per minute for $6 \mathrm{~h}$ collected in a final volume of $15 \mathrm{ml}$ ) correspond to $1.2 \mathrm{~m}^{3}$ of air sampled per ml of sampling liquid per hour $\left(1.2 \mathrm{~m}^{3} \mathrm{ml}^{-1} \mathrm{~h}^{-1}\right)$. Thus, the abundance of microbes in the air $C_{a i r}$ is given by,

$$
C_{\text {air }}=\frac{c}{1.2}
$$

Using the value of c from Equation (5), we calculated microbial abundance in the air using the abundances observed in the sample and the field blank and the sampling time $t$ using the following expression

$$
C_{\text {air }}=\frac{0.641751 N_{0}-0.641751 e^{0.7701 t} \cdot N(t)}{1-e^{0.7701 t}}
$$

where $C_{a i r}$ is the abundance of microbes in the air (particles $\mathrm{m}^{-3}$ ), $N(t)$ and $N_{0}$ are the microbial abundances in the sample and in the field blank, respectively, (microbes $\mathrm{ml}^{-1}$ ) and $t$ is the collection time (hours).

\section{MICROBIAL LOAD IN THE BOUNDARY LAYER}

The microbial loads ( $\mathrm{Q}$; particles per $\mathrm{m}^{2}$ of ocean surface), representing the concentration of microorganisms integrated over the atmospheric Boundary Layer Height (BLH), were calculated as the product between the microbial abundance in the air $\left(C_{a i r}\right)$, and the BLH as given by

$$
Q=C_{a i r} \cdot B L H
$$

assuming that the abundance of microorganisms is rapidly homogenized throughout the BLH by turbulent mixing (Lewis et al., 2004). Although there is a gradient in particle concentrations next to the surface of the ocean, gravitationally induced vertical gradients are negligible for small particles (Hoppel et al., 2002) and field measurements show that at moderate wind speeds such as those observed in our study, small particles become already well mixed at heights lower than $10 \mathrm{~m}$ (Piazzola and Despiau, 1997). The BLH values, computed by Troen and Mahrt (1986), were extracted from the Analysis from the European Center for Medium-range Weather Forecasts (ERA-Interim; Dee et al., 2011) and averaged from the fields every $3 \mathrm{~h}$ during 2 days previous to the observations and over an horizontal area that contained the air mass.

\section{CONCEPTUAL FRAMEWORK}

We considered two major processes, namely aerosolization from the ocean to the atmosphere and deposition from the atmosphere into the ocean as depicted in Figure 2. Direct flux measurements such as those performed on land (Lindemann et al., 1982; Lighthart and Shaffer, 1994) require sampling at fixed heights and are extremely challenging to implement at sea due to the disturbance caused by the constant rolling of the ship. Also, direct flux measurements provide only the net flux, but separate characterization of both aerosolization and deposition is more relevant for dispersal processes since the microbes entering and leaving the ocean at a given location may not belong to the same taxonomic groups. Therefore, we have calculated deposition and spray fluxes using variables that can be accurately measured on a ship and common parameterizations from the literature. Aerosolization promoted by wind shear over the sea surface was estimated from microbial abundance in surface waters and wind speed. Dry deposition of airborne microbes was estimated from meteorological conditions (wind speed, temperature and relative humidity) and microbial properties such as size and density. Transport over the ocean was estimated using a particle trajectory model (Draxler and Rolph, 2013) and residence times 


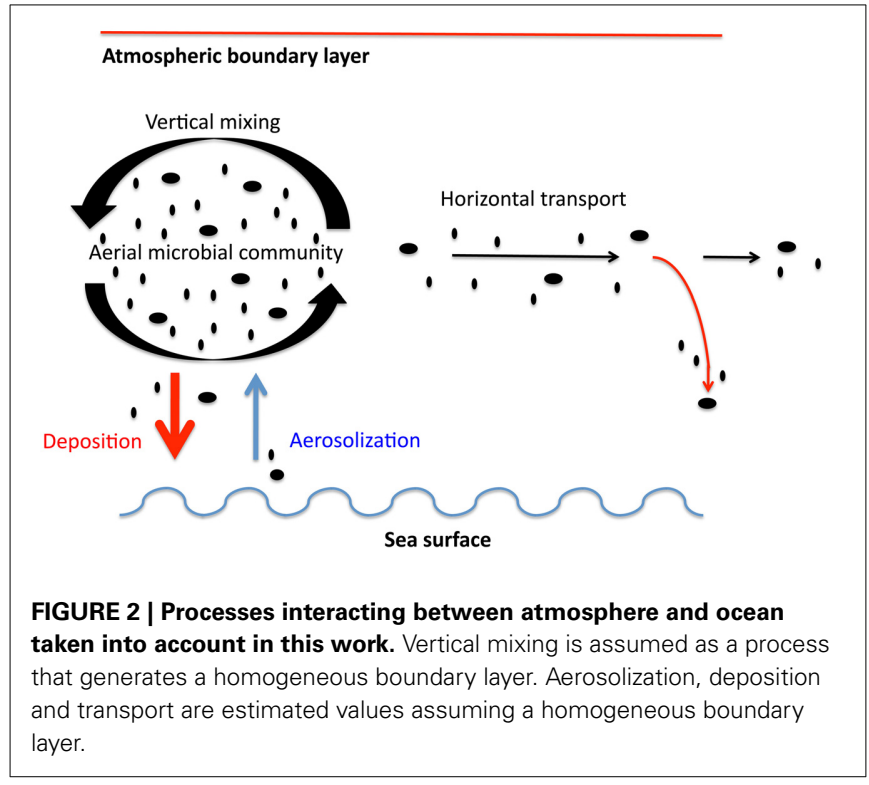

derived from microbial loads and deposition rates. Other processes, such as wet deposition, mass exchange at the top of the boundary layer or particle diffusion, were not taken into account in this study.

\section{DRY DEPOSITION OF AIRBORNE MICROORGANISMS ONTO THE OCEAN}

In this study we focused only on dry (not associated to snow or rainfall) deposition. Thus, the deposition velocity $\left(v_{d}, \mathrm{~m} \mathrm{~s}^{-1}\right)$ of airborne material can be parameterized as a function of the diameter and density of the particle and the atmospheric conditions (wind speed, temperature and humidity) (Williams, 1982). The deposition flux $(F d)$ can be estimated from $v_{d}$ as

$$
F d=v_{d} \cdot C_{a i r}
$$

where $\mathrm{C}_{\text {air }}$ is the air concentration of the particles, as described by Jurado et al. (2004 and Supplementary Material therein). The values of the atmospheric parameters necessary to compute $v_{d}$ (wind velocity, temperature, atmospheric pressure and humidity) were extracted as 2-min average values from the continuous recording of the meteorological station installed on board RV Pelagia. The mean value of the meteorological observations recorded during the $6 \mathrm{~h}$ of sampling was used to compute $v_{d}$. We assumed a density of $1.1 \mathrm{~g} \mathrm{~cm}^{-3}$ for biological particles (Bakken and Olsen, 1983) and a mean diameter of 0.5 and $5 \mu \mathrm{m}$ for prokaryotes and eukaryotes, respectively, as determined by epifluorescence microscopy. Anyway, deposition velocities were largely dependent on wind speed while assumptions regarding density and particle diameter had little effect on the calculated deposition velocity as shown in Figure 3 for the range of particle diameters considered and densities between 0.1 and $2 \mathrm{~g} \mathrm{~cm}^{-1}$.

\section{AEROSOLIZATION OF MARINE MICROBES INTO THE ATMOSPHERE}

Surface winds induce the formation of whitecaps and the subsequent generation of sea spray droplets, which carry sea salts and microbes into the atmosphere. Following Andreas (1998), the

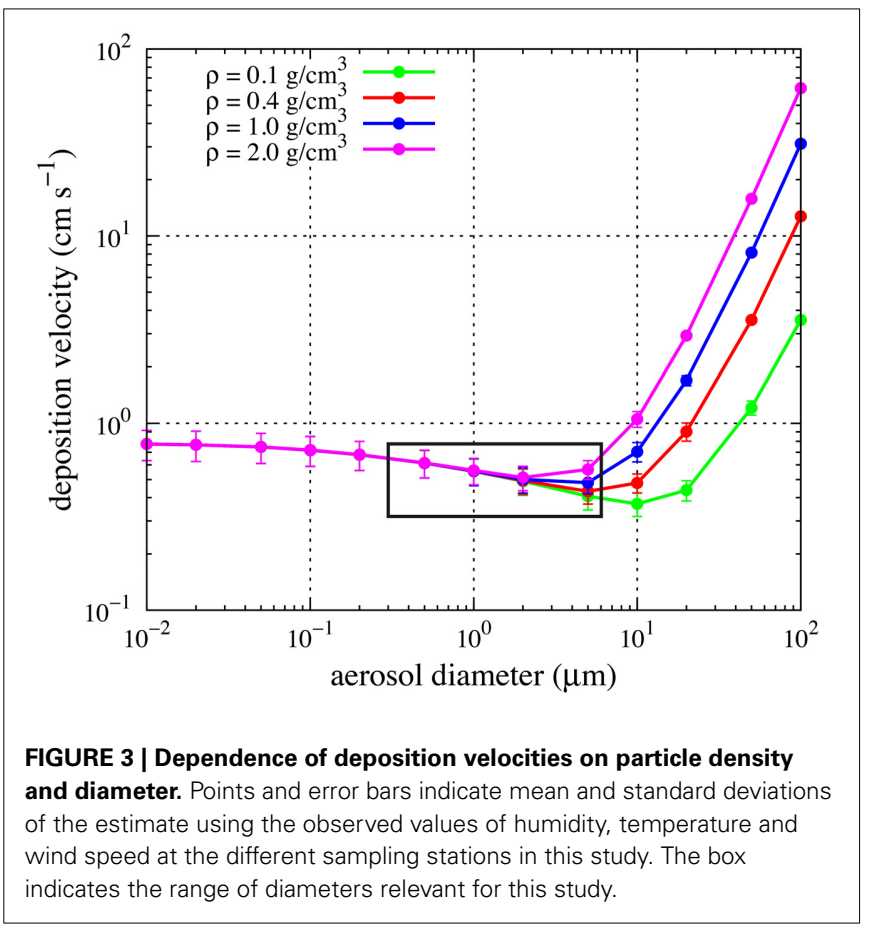

total volume flux of seawater spray into the atmosphere $\left(\dot{V}_{T}, \mathrm{~m}^{3}\right.$ $\left.\mathrm{m}^{-2} \mathrm{~s}^{-1}\right)$ is computed as:

$$
\dot{V}_{T}=\frac{4 \pi}{3} \int_{4}^{15} r_{0}^{3} \frac{d F}{d r_{0}} d r_{0}
$$

where $d F / d r_{0}$ is the spray generation function for droplets of an initial radius $r_{0}$ and it is computed as a function of the wind speed or the wind friction velocity $\left(u^{*}\right)$. Different formulations of $d F / d r_{0}$ have been proposed (cf. O'Dowd and de Leeuw, 2007) depending on the droplet radius and wind speed. For our calculations, we chose the formulation of Blanchard (1963) and Gathman (1982) as corrected by Andreas et al. (1995) using in situ observations of wind speed and humidity. This formulation is valid for wind speeds between 5 and $15 \mathrm{~m} \mathrm{~s}^{-1}$, well suited for the wind speeds observed during the MEDEA-II cruise (average $\sim 8 \mathrm{~m} \mathrm{~s}^{-1}$ ). We also constrained the estimation considering only droplets in the range of radii from 0.2 to $10 \mu \mathrm{m}$ as most microbial cells will be larger than $0.1 \mu \mathrm{m}$ and droplets $>10 \mu \mathrm{m}$ are not likely to remain airborne when the wind speed is lower than $9 \mathrm{~m} \mathrm{~s}^{-1}$ (Andreas et al., 1995). The choice of parameterization has little effect on the calculated spray fluxes, since other parameterizations of sea spray generation yield similar values for the particle size range between 0.1 and $10 \mu \mathrm{m}$ for wind speeds of $8 \mathrm{~m} \mathrm{~s}^{-1}$ (De Leeuw et al., 2011).

The flux of microbes associated to sea spray $(F s)$ was thus computed by multiplying the total volume flux $\dot{V}_{T}$ by the microbial abundances in sea surface water samples. Thus, the sea spray flux is comparable to the deposition flux (in terms of units) computed in the previous section. There are indications that microbial abundances in spray droplets may be higher than in surface waters 
(Blanchard et al., 1981), thus our estimate of spray flux calculation may be a minimum one. We did not attempt to correct for this enrichment since the reported enrichment factors vary enormously from day to day (Aller et al., 2005).

\section{REMAINING MICROBIAL LOAD IN THE ATMOSPHERE AND POTENTIAL FOR DISPERSAL}

The microorganisms suspended in the atmosphere are deposited according the Equation (9) and as determined by the following expression

$$
F d=-\frac{d Q}{d t}
$$

where $Q$ corresponds to the microbial load from Equation (8). Equating both Equations $(9,11)$, where $C_{\text {air }}$ is expressed as determined from Equation (8), and then integrating we obtained the remaining microbial load of suspended microorganisms at any given time as

$$
Q(t)=Q_{0} \cdot e^{\frac{-v_{d} \cdot t}{B L H}}
$$

where $Q(t)$ is the remaining microbial load, $Q_{0}$ initial microbial load and $t$ corresponds to time.

Forward trajectories were simulated using the HYSPLIT model (Draxler and Rolph, 2013) for particles originally situated at a height of $10 \mathrm{~m}$ above sea level at the sampling locations for the time necessary to reduce the microbial load to $10 \%$ of the original value as estimated from Equation (12). The distance traveled by the airborne microbes corresponds to the length of the estimated forward trajectories.

\section{RESULTS \\ ABUNDANCE OF AIRBORNE PROKARYOTES AND EUKARYOTES OVER THE NORTH ATLANTIC OCEAN}

The airborne prokaryotic abundance ranged from 2782 to 19,132 prokaryotes $\mathrm{m}^{-3}$ (average 8020 cells $\mathrm{m}^{-3}$ ) while the abundance of airborne eukaryotes ranged from 202 to 12,805 eukaryotes $\mathrm{m}^{-3}$ (average 1998 cells $\mathrm{m}^{-3}$, Table $\mathbf{1}$ ).

Lowest abundances of airborne bacteria were detected around $60^{\circ} \mathrm{N}$ and eukaryotic abundances generally decreased toward the North (Figure 4). Integrating the abundances of prokaryotes and eukaryotes over the height of the boundary layer resulted in an estimated microbial load ranging between $0.4 \times 10^{6}$ and $16 \times$

Table 1 | Abundance, derived spray and deposition fluxes and estimated load of airborne microorganisms over the North Atlantic Ocean obtained in this study (range is given in the upper row and

\begin{tabular}{|c|c|c|c|c|}
\hline & $\begin{array}{l}\text { Abundance } \\
\left(\text { cells } \mathbf{m}^{-3} \text { ) }\right.\end{array}$ & $\begin{array}{c}\text { Estimated } \\
\text { spray flux } \\
\text { (cells } \mathrm{m}^{-2} \mathrm{~s}^{-1} \text { ) }\end{array}$ & $\begin{array}{c}\text { Estimated } \\
\text { deposition flux } \\
\text { (cells } \mathrm{m}^{-2} \mathrm{~s}^{-1} \text { ) }\end{array}$ & $\begin{array}{l}\text { Estimated load } \\
\quad\left(\text { cells } \mathrm{m}^{-2}\right)\end{array}$ \\
\hline Prokaryotes & $\begin{array}{c}2782-19,132 \\
(8020)\end{array}$ & $\begin{array}{c}9.25-100.64 \\
(42.5)\end{array}$ & $\begin{array}{c}15.30-141.43 \\
(49.0)\end{array}$ & $\begin{array}{c}393,777- \\
16.082,289 \\
(3.651,764)\end{array}$ \\
\hline Eukaryotes & $\begin{array}{c}202-12,805 \\
(1998)\end{array}$ & $\begin{array}{c}0.01-0.1 \\
(0.04)\end{array}$ & $\begin{array}{c}1.05-64.02 \\
(9.85)\end{array}$ & $\begin{array}{c}60,571- \\
3.598,525 \\
(759,887)\end{array}$ \\
\hline
\end{tabular}
averages in the lower row).
$10^{6}$ prokaryote cells $\mathrm{m}^{-2}$ and $6 \times 10^{4}$ to almost $3.6 \times 10^{6}$ eukaryote cells $\mathrm{m}^{-2}$ (Table 1 ). The height of the boundary layer showed large variations along the sampled track ranging between 93 and $919 \mathrm{~m}$, with the lowest heights related to strong subsidence in the upper atmosphere and presence of fog, but the general pattern of the estimated microbial load was mainly determined by the microbial abundance.

\section{AEROSOLIZATION AND DEPOSITION FLUXES AND TRANSPORT OF AIRBORNE MICROBES}

Mean wind speed during the MEDEA-II cruise was $7.9 \pm 3.3 \mathrm{~m}$ $\mathrm{s}^{-1}$ and the prokaryotic abundances in surface seawater samples ranged from $8 \times 10^{5}$ to $2.3 \times 10^{6}$, resulting in averaged emissions with spray of 42.5 prokaryotes $\mathrm{m}^{-2} \mathrm{~s}^{-1}$ (range 9.25-100.64 prokaryotes $\mathrm{m}^{-2} \mathrm{~s}^{-1}$ ). The abundance of small eukaryotic cells in surface seawater was not measured but we calculated order-ofmagnitude estimates ranging from 0.01 to 0.1 eukaryotes $\mathrm{m}^{-2} \mathrm{~s}^{-1}$ (average 0.04 eukaryotes $\mathrm{m}^{-2} \mathrm{~s}^{-1}$, Figure 5) assuming a constant relationship between the abundance of heterotrophic bacteria and small protists in surface seawater (Zubkov et al., 2007).

The derived average deposition fluxes were 49.0 prokaryotes $\mathrm{m}^{-2} \mathrm{~s}^{-1}$ and 9.85 eukaryotes $\mathrm{m}^{-2} \mathrm{~s}^{-1}$ ranging from 15.30 to 141.43 prokaryotes $\mathrm{m}^{-2} \mathrm{~s}^{-1}$ and from 1.05 to 64.02 eukaryotes $\mathrm{m}^{-2} \mathrm{~s}^{-1}$ (Figure 5). Net fluxes calculated as spray fluxes minus deposition fluxes (negative values denote net flux into the ocean) averaged -6.49 prokaryotes $\mathrm{m}^{-2} \mathrm{~s}^{-1}$ and -9.81 eukaryotes $\mathrm{m}^{-2}$ $\mathrm{s}^{-1}$. Net fluxes of prokaryotes were negative in $45 \%$ of sampled locations, while the ocean was a net sink for eukaryotes at all stations sampled (Figure 6). The locations where the ocean acted as a net source of microorganisms to the atmosphere were mostly situated south of $60^{\circ} \mathrm{N}$.

The estimated deposition rates indicated that the time necessary to deposit $50 \%$ of the suspended cells was on average 0.6 and 0.7 days for prokaryotes and eukaryotes, respectively, (maximum 1.2 and 1.4 days). Moreover, our calculations also indicated that $10 \%$ of the suspended microbes remained airborne after 4 (prokaryotes) and 4.8 days (eukaryotes) at some locations (average 2 and 2.4 days for prokaryotes and eukaryotes, respectively). Moreover, it was estimated that $1 \%$ of the sampled microbes were still airborne after up 8 (prokaryotes) and 9.6 days (eukaryotes) on average 4 and 4.8 days, respectively. Modeling forward trajectories for the time required to reduce the microbial load to $10 \%$ of the original revealed that $90 \%$ of the prokaryotes were deposited over distances between 6308 and 10,337 km, with an average of $8273 \mathrm{~km}$, while $10 \%$ of the eukaryotes were still airborne after traveling from 6499 to $11,379 \mathrm{~km}$, with an average of $8623 \mathrm{~km}$ (Figure 1).

\section{DISCUSSION}

It is difficult to compare our results to other oceanic estimates since only very few studies have been conducted at open oceanic locations. Indeed, Burrows et al. (2009b) did not report any abundance estimates for remote oceanic locations, simply because these were absent from the literature at that time. Other, more recent studies on airborne bacteria over the ocean derive from locations either influenced by terrestrial sources (Cho and Hwang, 2011) or from high altitudes well above the boundary 

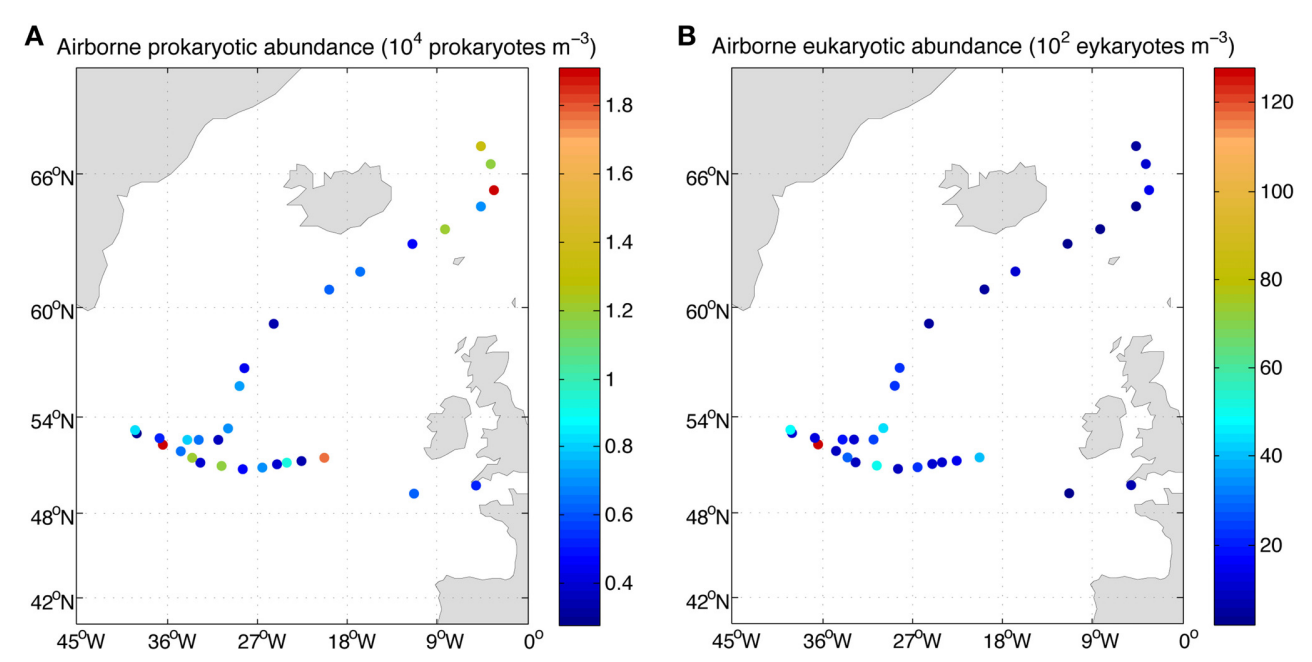

FIGURE 4 | Concentration of airborne prokaryotes (A) and eukaryotes (B) over the eastern North Atlantic along the MEDEA-Il cruise.
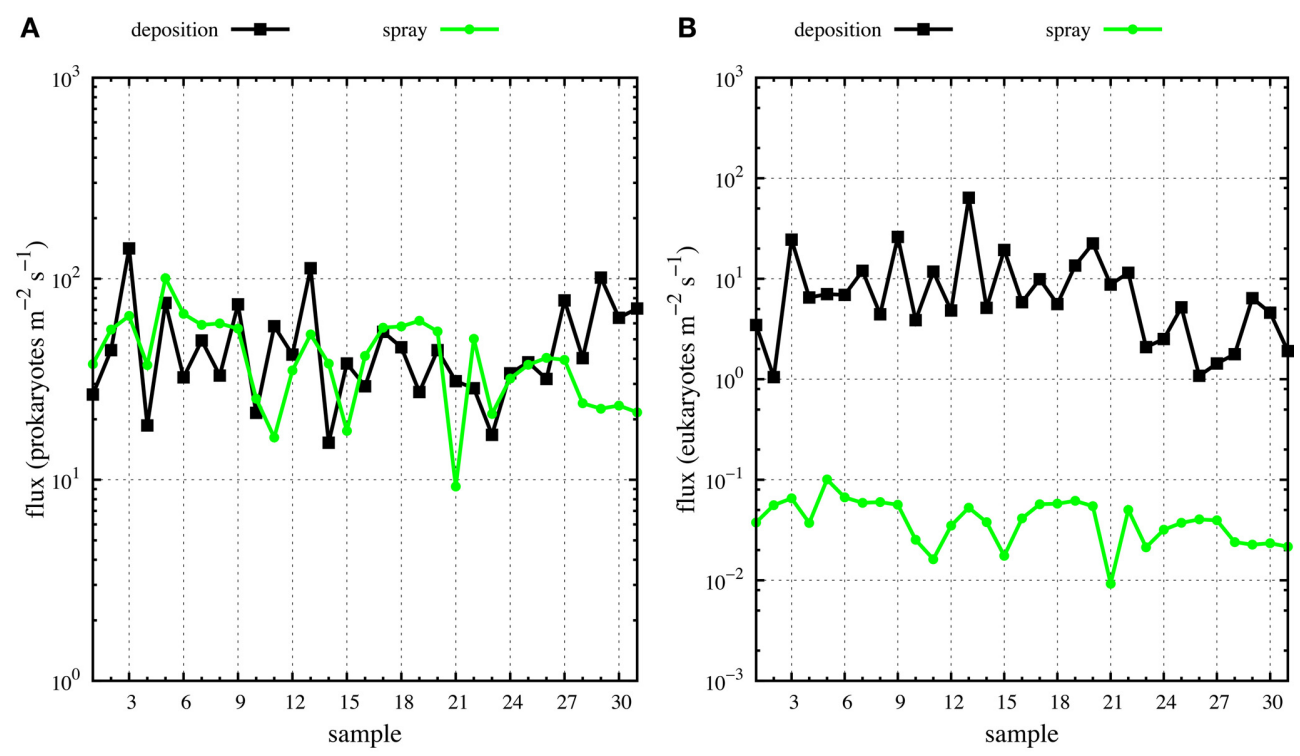

FIGURE 5 | Deposition (black dots) and spray (green dots) fluxes of airborne prokaryotes (A) and eukaryotes (B) along MEDEA-II cruise.

layer (Smith et al., 2012; Yamaguchi et al., 2012; DeLeonRodriguez et al., 2013). The abundance of airborne prokaryotes and eukaryotes reported in our study are between 10 and 100fold lower than those reported in other studies (Cho and Hwang, 2011; DeLeon-Rodriguez et al., 2013). These differences are probably due to the fact that none of those studies is representative for the atmospheric boundary layer of the open ocean as well as to methodological differences. Even studies developed in the atmospheric boundary layer over open sea are difficult to compare with our data, because the differences among data sets are probably due to the use of different counting methods. For example, airborne microbial abundances reported by Marks et al. (2001) from the Baltic Sea, resulted in one and two order of magnitude lower than those reported in our study for eukaryotes and prokaryotes, respectively, probably due to the low efficiency of cultivation-dependent counts. Conversely, Cho and Hwang (2011) reported abundances of airborne bacteria ranging from 0.7 to $1.2 \times 10^{5}$ cells $\mathrm{m}^{-3}$ using epifluorescence microscopy, one order of magnitude higher than our values, probably due to the fact that their samples come from a nearly-enclosed sea heavily influenced by land. Similarly, Matthias-Maser et al. (1999) reported average values of $5.9 \times 10^{5}$ biological particles in an area affected by African dust episodes. Also, the higher abundances obtained by microscopic counts reported by DeLeon-Rodriguez et al. (2013) correspond to high altitude samples and influenced by hurricanes. However, these authors reported bacterial 

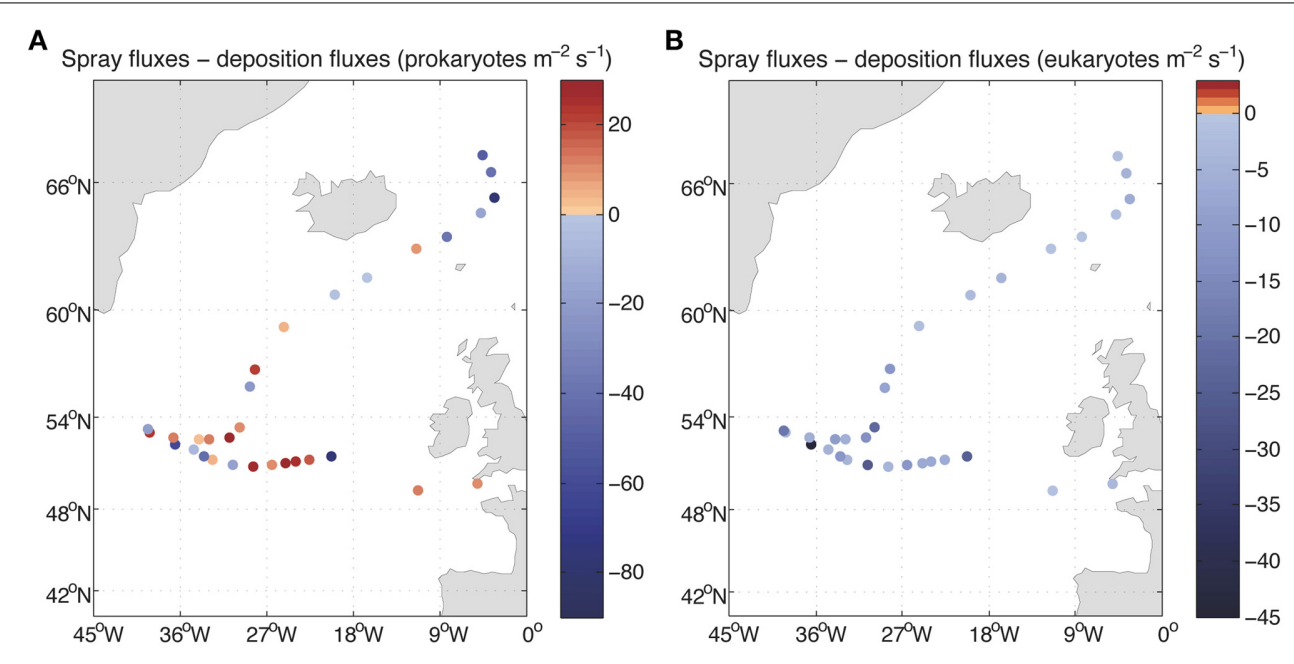

FIGURE 6 | Net fluxes of prokaryotes (A) and eukaryotes (B) between air and sea. The values lower than zero correspond to net fluxes from the atmosphere into the ocean.

abundances exceeding their own estimates of total particles in the sample. The authors explained these discrepancies by the low accuracy of their bacterial counts resulting from the very low abundance in their samples. Indeed, these authors counted only 16 microscopic fields while we estimated that up to 150 fields must be counted to obtain reliable results below the $10 \%$ relative standard deviation threshold in low abundance samples (see Materials and Methods). Yet, qPCR estimates of bacterial abundance reported in the same studies (Cho and Hwang, 2011; DeLeon-Rodriguez et al., 2013) result in much lower abundances similar to the range of $10^{3}-10^{4}$ cells $\mathrm{m}^{-3}$ that we found over the North Atlantic Ocean although these estimates are expected to yield overestimates of microbial abundance due to the presence of multiple copies of the rRNA operon. Hence, the abundances of airborne microbes reported here for the open North Atlantic Ocean are the first estimates reported thus far for open-oceanic locations.

Collecting airborne microbes in liquid systems might result in large sample losses by re-aerosolization such as those reported for impingers (Riemenschneider et al., 2010), swirling liquid collectors (Willeke et al., 1998) or those reported in this paper for our cyclonic sampler. However, these losses can be corrected quite accurately (see Materials and Methods). Moreover, liquid samples have the advantage that they can be processed using standard methods developed for aquatic microbiology. Contamination may, however, be an issue in liquid samples, but microbial abundances in field blanks were always much lower than those in the samples indicating that the microbes were actually derived from the atmosphere. Moreover, due to the exponential dilution observed over time in the experiments with fluorescent microspheres, the expected contribution of any contaminating microbes present at the onset of the collection on the final estimated abundance is negligible. Collection efficiencies vary widely among different samplers for different particle sizes (Nevalainen et al., 1992; Dybwad et al., 2014). It has been reported that for our Coriolis sampler, the physical sampling efficiency for particles in the size range of bacteria $(0.2-1.0 \mu \mathrm{m}$ in diameter) is around $50 \%$ but close to $100 \%$ for particles larger than $4 \mu \mathrm{m}$ (Carvalho et al., 2008; Dybwad et al., 2014). We did not attempt to correct for this since the reported low collection efficiencies are mainly due to re-aerosolization for which we already corrected and also because many of the airborne bacteria can be attached to larger particles.

The forward trajectories of the air masses sampled here over the North Atlantic Ocean are consistent with global patterns of atmospheric circulation, with a high-pressure system over Greenland generating northerly winds in the north section of MEDEA-II cruise. A low-pressure system over the Atlantic Ocean (below $60^{\circ} \mathrm{N}$ ) generated southerly and westerly winds in the southern region of MEDEA-II cruise. These modeled trajectories, together with our estimates of residence time, suggest that most airborne bacteria at the stations sampled were of oceanic origin.

Estimations of airborne microbial abundance over the open ocean are needed to resolve the biology of the atmosphere, the Earth's biome where life is most diluted but that, as demonstrated for other similarly diluted constituents (e.g., nitrogen, pollutants or gasses), plays a fundamental role in transport and connectivity across biomes (Uematsu et al., 1983; Krishnamurthy et al., 2010). Determining the concentration and loads of atmospheric microbes is an important step, and the estimates provided here suggest that microbes are diluted in the atmosphere more than 9 or 11 orders of magnitude relative to their concentration in seawater or soils (Whitman et al., 1998). This could lead to the conclusion that airborne bacteria are unimportant and can be neglected. Yet, the abundance of airborne microbes may be a misleading indicator of the importance of this compartment, as the atmosphere may play a major role in the dispersal of microbes, in the connectivity and the maintenance of diversity in the surface ocean or in regulating climatic processes through the role of airborne bacteria as nuclei of accretion for cloud and ice formation. Hence, while diluted relative to the marine or soil compartment, the estimated microbial load over the height of the boundary layer averaging $3.6 \times 10^{6}$ prokaryotes $\mathrm{m}^{-2}$ and $7.6 \times 10^{5}$ eukaryotes 
$\mathrm{m}^{-2}$ represents a formidable seed bank hovering over the North Atlantic Ocean. The net fluxes are relatively small (Figure 6) compared to those reported for land locations. Bacterial net flux measurements over a chaparral, oscillated over the day between -8 and 5 CFU m ${ }^{2} \mathrm{~s}^{-1}$ (Lighthart and Shaffer, 1994) while only

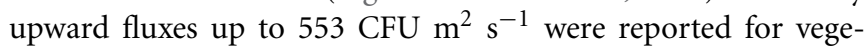
tated agricultural soils (Lindemann et al., 1982), if we consider that cultivable bacteria may be about $1 \%$ of the total bacterial load, our net bacterial fluxes could be up to 4 orders of magnitude lower. However, the microbes entering and leaving the surface ocean are not necessarily the same and thus, the calculated air-sea exchange of microbes shows that it is a highly dynamic process. Averages of $3.6 \times 10^{6}$ prokaryotes and $3.7 \times 10^{3}$ eukaryotes per square meter leaving the ocean into the atmosphere every day were calculated in this study, while an average of $4.2 \times 10^{6}$ prokaryotes and $8.5 \times 10^{5}$ eukaryotes per square meter enter the surface ocean from the atmosphere every day. These values evidence a rapid turnover of atmospheric microbes but also a high dispersal capacity since $10 \%$ of the microorganisms present in a given sample will still be airborne on average after 2 days in the case of prokaryotes and 2.4 days for eukaryotes and $1 \%$ will still be airborne on average after 4 days (prokaryotes) and 4.8 days (eukaryotes). In other words, $90 \%$ of the microbes present in the original air sample will be deposited in about 2 days over large stretches of the ocean $>8000 \mathrm{~km}$ long.

In conclusion, we found atmospheric microbial abundances in the boundary layer over the North Atlantic Ocean ranging from $10^{3}$ to $10^{4}$ prokaryotes $\mathrm{m}^{-3}$ and from $10^{2}$ to $10^{4}$ eukaryotes $\mathrm{m}^{-3}$, but supporting daily air-sea exchanges in the order of millions of prokaryotes and thousands of unicellular eukaryotes per square meter of oceanic surface. This limited dataset provides a first snapshot of the microbial abundances and fluxes over the North Atlantic Ocean during our cruise. Additional efforts are needed to assess the temporal variability and the magnitude of these processes in this and other regions of the ocean. Calculations based on current parameterizations are crude and should be considered as order-of-magnitude estimates. Nevertheless, our data point to a rapid exchange of microbes between the atmosphere and the surface ocean, which is not apparent from abundance data only. This rapid flux could be of major importance for the dispersal of marine microbes and for the maintenance of local diversity over the global ocean.

\section{ACKNOWLEDGMENTS}

This is a contribution to the Malaspina Expedition 2010, funded by the INGENIO 2010 CONSOLIDER program (ref. CDS200800077) of the Spanish Ministry of Economy and Competitiveness, and projects from the Austrian Science Fund (FWF, I486-B09 and P23234-B11) and project MEDEA from the European Research Council under the European Community's Seventh Framework Programme (FP7/2007-2013, ERC grant agreement No. 268595). We thank the crew of R/V Pelagia for their invaluable support, J. Baldrich for his help with processing samples and the NOAA Air Resources Laboratory (ARL) for the provision of the HYSPLIT model (http://www.ready.noaa.gov) used in this publication. Eva Mayol and María A. Jiménez acknowledge the "Junta para la Ampliación de Estudios" program (JAE-predoc and JAE-doc contracts, respectively) from CSIC, supplied by the European Social Fund. Jesús M. Arrieta was supported by a "Ramón y Cajal" fellowship by the former Ministry of Science and Innovation of the Spanish Government.

\section{REFERENCES}

Aller, J. Y., Kuznetsova, M. R., Jahns, C. J., and Kemp, P. F. (2005). The sea surface microlayer as a source of viral and bacterial enrichment in marine aerosols. J. Aerosol Sci. 36, 801-812. doi: 10.1016/j.jaerosci.2004.10.012

Amann, R. I., Ludwig, W., and Schleifer, K. H. (1995). Phylogenetic identification and in situ detection of individual microbial cells without cultivation. Microbiol. Rev. 59, 143-169.

Andreas, E. L. (1998). A new sea spray generation function for wind speeds up to $32 \mathrm{~m} \mathrm{~s}$-1. J. Phys. Oceanogr. 28, 2175-2184.

Andreas, E. L., Edson, J. B., Monahan, E. C., Rouault, M. P., and Smith, S. D. (1995). The spray contribution to net evaporation from the sea: a review of recent progress. Bound.-Layer Meteorol. 72, 3-52. doi: 10.1007/BF00712389

Bakken, L. R., and Olsen, R. A. (1983). Buoyant densities and dry-matter contents of microorganisms: conversion of a measured biovolume into biomass. Appl. Environ. Microbiol. 45, 1188-1195.

Blanchard, D. C. (1963). The electrification of the atmosphere by particles from bubbles in the sea. Prog. Oceanogr. 1, 73-202. doi: 10.1016/00796611(63)90004-1

Blanchard, D. C., Syzdek, L. D., and Weber, M. E. (1981). Bubble scavenging of bacteria in freshwater quickly produces bacterial enrichment in air-borne jet drops. Limnol. Oceanogr. 26, 961-964. doi: 10.4319/lo.1981.26.5.0961

Burrows, S. M., Butler, T., Jöckel, P., Tost, H., Kerkweg, A., Pöschl, U., et al. (2009a). Bacteria in the global atmosphere-Part 2: modeling of emissions and transport between different ecosystems. Atmos. Chem. Phys. 9, 9281-9297. doi: 10.5194/acp-9-9281-2009

Burrows, S. M., Elbert, W., Lawrence, M. G., and Pöschl, U. (2009b). Bacteria in the global atmosphere-Part 1: review and synthesis of literature data for different ecosystems. Atmos. Chem. Phys. 9, 9263-9280. doi: 10.5194/acp-9-9263-2009

Carvalho, E., Sindt, C., Verdier, A., Galan, C., O’Donoghue, L., Parks, S., et al. (2008). Performance of the Coriolis air sampler, a high-volume aerosolcollection system for quantification of airborne spores and pollen grains. Aerobiologia 24, 191-201. doi: 10.1007/s10453-008-9098-y

Cho, B. C., and Hwang, C. Y. (2011). Prokaryotic abundance and 16S rRNA gene sequences detected in marine aerosols on the East Sea (Korea): prokaryotes above the East Sea. FEMS Microbiol. Ecol. 76, 327-341. doi: 10.1111/j.15746941.2011.01053.x

Christner, B. C., Morris, C. E., Foreman, C. M., Cai, R., and Sands, D. C. (2008). Ubiquity of biological ice nucleators in snowfall. Science 319, 1214-1214. doi: 10.1126/science.1149757

Dee, D. P., Uppala, S. M., Simmons, A. J., Berrisford, P., Poli, P., Kobayashi, S., et al. (2011). The ERA-Interim reanalysis: configuration and performance of the data assimilation system. Q. J. R. Meteorol. Soc. 137, 553-597. doi: 10.1002/ qj. 828

De Leeuw, G., Andreas, E. L., Anguelova, M. D., Fairall, C. W., Lewis, E. R., O’Dowd, C., et al. (2011). Production flux of sea spray aerosol. Rev. Geophys. 49, RG2001. doi: 10.1029/2010RG000349

DeLeon-Rodriguez, N., Lathem, T. L., Rodriguez-R, L. M., Barazesh, J. M., Anderson, B. E., Beyersdorf, A. J., et al. (2013). Microbiome of the upper troposphere: species composition and prevalence, effects of tropical storms, and atmospheric implications. Proc. Natl. Acad. Sci. U.S.A. 110, 2575-2580. doi: 10.1073/pnas.1212089110

Després, V. R., Alex Huffman, J., Burrows, S. M., Hoose, C., Safatov, A. S., Buryak, G., et al. (2012). Primary biological aerosol particles in the atmosphere: a review. Tellus B 64:15598. doi: 10.3402/tellusb.v64i0.15598

Draxler, R. R., and Rolph, G. D. (2013). HYSPLIT (HYbrid Single-Particle Lagrangian Integrated Trajectory) Model access via NOAA ARL READY Website. Silver Spring, MD: NOAA Air Resources Laboratory, 2011.

Dybwad, M., Skogan, G., and Blatny, J. M. (2014). Comparative testing and evaluation of nine different air samplers: end-to-end sampling efficiencies as specific performance measurements for bioaerosol applications. Aerosol Sci. Technol. 48, 282-295. doi: 10.1080/02786826.2013.871501

Gathman, S. G. (1982). A Time-Dependent Oceanic Aerosol Profile Model. Washington, DC: NRL Rep. 8536, Naval Research Laboratory. 
Hervàs, A., Camarero, L., Reche, I., and Casamayor, E. O. (2009). Viability and potential for immigration of airborne bacteria from Africa that reach high mountain lakes in Europe. Environ. Microbiol. 11, 1612-1623. doi: 10.1111/j.1462-2920.2009.01926.x

Hoppel, W. A., Frick, G. M., and Fitzgerald, J. W. (2002). Surface source function for sea-salt aerosol and aerosol dry deposition to the ocean surface. J. Geophys. Res. Atmos. 107, 4382. doi: 10.1029/2001JD002014

Jurado, E., Jaward, F. M., Lohmann, R., Jones, K. C., Simó, R., and Dachs, J. (2004). Atmospheric dry deposition of persistent organic pollutants to the atlantic and inferences for the global oceans. Environ. Sci. Technol. 38, 5505-5513. doi: 10.1021/es049240v

Krishnamurthy, A., Moore, J. K., Mahowald, N., Luo, C., and Zender, C. S. (2010). Impacts of atmospheric nutrient inputs on marine biogeochemistry. J. Geophys. Res. Biogeosci. 115, G01006. doi: 10.1029/2009JG001115

Lewis, E. R., Schwartz, S. E., Lewis, E. R., and Schwartz, S. E. (2004). "Fundamentals," in Sea Salt Aerosol Production: Mechanisms, Methods, Measurements and Models - A Critical Review (American Geophysical Union), 9-99. Available online at: http://onlinelibrary.wiley.com/

Lighthart, B., and Shaffer, B. T. (1994). Bacterial flux from chaparral into the atmosphere in mid-summer at a high desert location. Atmos. Environ. 28, 1267-1274. doi: 10.1016/1352-2310(94)90273-9

Lindemann, J., Constantinidou, H. A., Barchet, W. R., and Upper, C. D. (1982). Plants as sources of airborne bacteria, including ice nucleation-active bacteria. Appl. Environ. Microbiol. 44, 1059-1063.

Marie, D., Partensky, F., Jacquet, S., and Vaulot, D. (1997). Enumeration and cell cycle analysis of natural populations of marine picoplankton by flow cytometry using the nucleic acid stain SYBR Green I. Appl. Environ. Microbiol. 63, 186-193.

Marks, R., Kruczalak, K., Jankowska, K., and Michalska, M. (2001). Bacteria and fungi in air over the Gulf of Gdañsk and Baltic sea. J. Aerosol Sci. 32, 237-250. doi: 10.1016/S0021-8502(00)00064-1

Matthias-Maser, S., Brinkmann, J., and Schneider, W. (1999). The size distribution of marine atmospheric aerosol with regard to primary biological aerosol particles over the South Atlantic Ocean. Atmos. Environ. 33, 3569-3575. doi: 10.1016/S1352-2310(98)00121-6

Morris, C. E., Conen, F., Alex Huffman, J., Phillips, V., Pöschl, U., and Sands, D. C. (2014). Bioprecipitation: a feedback cycle linking Earth history, ecosystem dynamics and land use through biological ice nucleators in the atmosphere. Glob. Change Biol. 20, 341-351. doi: 10.1111/gcb.12447

Nevalainen, A., Pastuszka, J., Liebhaber, F., and Willeke, K. (1992). Performance of bioaerosol samplers: collection characteristics and sampler design considerations. Atmosp. Environ. Part A Gen. Top. 26, 531-540. doi: 10.1016/09601686(92)90166-I

O'Dowd, C. D., and de Leeuw, G. (2007). Marine aerosol production: a review of the current knowledge. Philos. Trans. R. Soc. Math. Phys. Eng. Sci. 365, 1753-1774. doi: 10.1098/rsta.2007.2043

Petelski, T., and Piskozub, J. (2006). Vertical coarse aerosol fluxes in the atmospheric surface layer over the North Polar Waters of the Atlantic. J. Geophys. Res. 111:C06039. doi: 10.1029/2005JC003295

Piazzola, J., and Despiau, S. (1997). Vertical distribution of aerosol particles near the air-sea interface in coastal zone. J. Aerosol Sci. 28, 1579-1599. doi: 10.1016/S0021-8502(97)00020-7

Polymenakou, P. N., Mandalakis, M., Stephanou, E. G., and Tselepides, A. (2007). Particle size distribution of airborne microorganisms and pathogensduring an intense african dust event in the eastern mediterranean. Environ. Health Perspect. 116, 292-296. doi: 10.1289/ehp.10684

Porter, K. G., and Feig, Y. S. (1980). The use of DAPI for identifying and counting aquatic microflora. Limnol. Oceanogr. 25, 943-948.

Riemenschneider, L., Woo, M.-H., Wu, C.-Y., Lundgren, D., Wander, J., Lee, J.-H., et al. (2010). Characterization of reaerosolization from impingers in an effort to improve airborne virus sampling. J. Appl. Microbiol. 108, 315-324. doi: 10.1111/j.1365-2672.2009.04425.x

Sherr, E., Caron, D. A., and Sherr, B. F. (1993). "Staining of heterotrophic protists for visualization via epifluorescence microscopy," in Handbook of methods in aquatic microbial ecology, eds. P. F. Kemp, B. F. Sherr, E. Sherr, and J. J. Cole (CRC Press), 213-228.

Smith, D. J., Jaffe, D. A., Birmele, M. N., Griffin, D. W., Schuerger, A. C., Hee, J., et al. (2012). Free tropospheric transport of microorganisms from Asia to North America. Microb. Ecol. 64, 973-985. doi: 10.1007/s00248-012-0088-9

Troen, I. B., and Mahrt, L. (1986). A simple model of the atmospheric boundary layer; sensitivity to surface evaporation. Bound.-Layer Meteorol. 37, 129-148. doi: $10.1007 / B F 00122760$

Uematsu, M., Duce, R. A., Prospero, J. M., Chen, L., Merrill, J. T., and McDonald, R. L. (1983). Transport of mineral aerosol from Asia Over the North Pacific Ocean. J. Geophys. Res. Oceans 88, 5343-5352. doi: 10.1029/JC088iC09p05343

Whitman, W. B., Coleman, D. C., and Wiebe, W. J. (1998). Prokaryotes: the unseen majority. Proc. Natl. Acad. Sci. U.S.A. 95, 6578-6583. doi: 10.1073/pnas.95.12.6578

Willeke, K., Lin, X., and Grinshpun, S. A. (1998). Improved aerosol collection by combined impaction and centrifugal motion. Aerosol Sci. Technol. 28, 439-456. doi: 10.1080/02786829808965536

Williams, R. M. (1982). A model for the dry deposition of particles to natural water surfaces. Atmos. Environ. 16, 1933-1938. doi: 10.1016/0004-6981(82) 90464-4

Yamaguchi, N., Ichijo, T., Sakotani, A., Baba, T., and Nasu, M. (2012). Global dispersion of bacterial cells on Asian dust. Sci. Rep. 2:525. doi: 10.1038/srep 00525

Zubkov, M. V., Burkill, P. H., and Topping, J. N. (2007). Flow cytometric enumeration of DNA-stained oceanic planktonic protists. J. Plankton Res. 29, 79-86. doi: 10.1093/plankt/fbl059

Conflict of Interest Statement: The authors declare that the research was conducted in the absence of any commercial or financial relationships that could be construed as a potential conflict of interest.

Received: 25 July 2014; accepted: 06 October 2014; published online: 31 October 2014. Citation: Mayol E, Jiménez MA, Herndl GJ, Duarte CM and Arrieta JM (2014) Resolving the abundance and air-sea fluxes of airborne microorganisms in the North Atlantic Ocean. Front. Microbiol. 5:557. doi: 10.3389/fmicb.2014.00557

This article was submitted to Aquatic Microbiology, a section of the journal Frontiers in Microbiology.

Copyright (c) 2014 Mayol, Jiménez, Herndl, Duarte and Arrieta. This is an openaccess article distributed under the terms of the Creative Commons Attribution License (CC BY). The use, distribution or reproduction in other forums is permitted, provided the original author(s) or licensor are credited and that the original publication in this journal is cited, in accordance with accepted academic practice. No use, distribution or reproduction is permitted which does not comply with these terms. 